Much of the discussion of the rogulation of metabolic patterns is written around the authors' own view of the dovelopment of drug resistance and the adaptation to growth on new substrates, which can often increase apparently gradually upon continued sub-culturo. These chapters (7-9) discuss in great detail the evidence for the anthors' own viewpoint that the permanent or semipermanent changes produced are not caused by the selection of mutants which occur independently of the agent but by an overall change in the metabolic network of most, of the organisms exposed to the drug which leads to a new "total integration". Drug resistance caused by infectious particles (episomes) discovered in Japan in 1959 is not discussed; likewise the fluctuation test ${ }^{2}$ is curtly dismissed in a paragraph in small type in Chapter 13 which is supposed to discuss mutation and sclection. Nevertheloss, without agreeing with the authors' curt dismissal of many of the basic claims of microbial genetics it is possible to agreo partially with their more general eriticism of many molecular biologists who imply that there is a single overall cellular regulating system and that this lies solely in the roprossion, depression and replieation of deoxyribonucloic acid. Kinetic models of cellular networks and control mechanisms other than those of Dean and Hinshelwood, especially, say, by Kaeser or Goodwin, already stress that this may be a gross oversimplification due perhaps to its being formulated too hurriedly and in the flush of the success of the solving of the genctic code for protein structure. Nevertheloss, a hypothesis such as the Jacob and Monod model for regulating protein synthesis is so outstandingly successful in generating an exporimental approach to the basis of growth and regulation that it cannot therefore be so lightly dismissed as do Dr. Dean and Sir Cyril. It is possible to read into their treatment of those aspects of modern biochemistry a general suspicion by them of all work which deals with less integrated systems than whole cells. This arises quite naturally from their own formulation of "totally integrated systems" and is reminiscent of early criticisms of the application of chemistry and physics to biology and so ably disputed by Sir Frederick Gowland Hopkins. Here, however, the authors' view quite plainly does not arise from any new vitalism, but from a probable reluctance, not plainly expressed, to accept the relovanco of results gained from the necessity of working with partial systems isolated, it is true, by relatively crude methods.

D. E. HuGHES

' Kormberg, H., Essays in Biochemistry (edit. by Campbell, P. N., and fireville, G. O.), 2 (Academie Prese, 1966).

${ }^{2}$ Hayes, W., The Genetics of Bacteria and their Viruses (Blackwell, 1964).

\section{BREATH OF LIFE}

\section{Development of the Lung}

Edited by A. V. S. de Reuck and Ruth Porter. (Ciba Foundation Symposium.) Pp. xiii +408. (London: .J. and A. Churchill, Ltd., 1967.) 658.

THIs Ciba Symposium has contributions from experts in many different fields and should prove valuable in broaden. ing the outlook of all students of respiration. This will apply particularly to those who study man, for they are inclined to look askance at any creature which does not impose on itself the grave respiratory and circulatory disadvantages of an upright posture. The fact that the footus has to make a remarkablo respiratory adaptation at birth gave the organizers at the Ciba Foundation the opportunity to call together marine biologists, zoologists and biochemists, as well as the paediatricians, anatomists and physiologists who would havo made a more convontional group. This report of the meeting, under the chairmanship of Dr. Philip Hugh-Jones, has produced some excellent papors, grouped under the headings of lung phylogeny, ontogeny and the gas/liquid interphase. There are further sections in which intra-uterine gas exchange and the onset of broathing are considered.

The courage shown by the organizers has boen rewarded by contributions which will stand in their own right as signposts for further work and some may well remain as milestones. Although the organizers had doubted whether a new symposium on the lung was advisable so soon after the important Pulmonary Structure and Function (Ciba Foundation Symp., Churehill, London, 1962), one finds that in the event there is new knowledge, a different emphasis and perhaps more balanced judgments after this short interval.

As one who was privileged to attend the symposium, and is concerned. with the field, it would be invidious to select individual articles for praise. All who were present learned a great deal, and this judiciously edited account of the proceedings now makes both required and attractive reading for a larger public.

K. W. Cross

\section{INTRODUCTION TO ORNITHOLOGY}

\section{The Shell Bird Book}

By James Fisher. Pp. 344+20 plates. (London: Ebury Press and Michael Joseph, 1966.) $25 s$.

THIs book about birds, birdwatehing and ornithologist in Britain and Ireland contains a lot of information, some of it published bofore but not easily accessible. There are soctions about the history of birds in these islands from fossil records and from the earliest written records, about the people who have studied birds and the parts played by birds in literature, art and music. There are chapters on how migration is studied, on taxonomic and ecological status and on the history of bird protection. Practical information such as lists of song recordings, books, societies and sites for birdwatching and what to do for birds in gardens is given. The book ends with a systematic list that records briefly the status of the species as fossils, in historical times and today. Inevitably the scientific treatment of any of these subjects is slight, but the book may introduce it to many people.

An important feature is the illustrations. Those in colour will be remembered from the Shell advertisements and are by contemporary artists. 'They include views of places familiar to ornithologists and forty-eight of Ennion's delightful sketches of birds. The text figures include many woodeuts from older books and portraits of ornithologists.

F. A. L. Clowtes

\section{RAISING BLOOD PRESSURE}

\section{Hypotensive Peptides}

Fdited by Frvin G. Erdös, Nathan Back and Federigo Sicuteri. (Proceedings of the International Symposium, ()tober 25-29, 1965, Florence, Italy.) Pp. xxvi +660. (Berlin and Now York: Springer-Verlag, 1966.) 74.40 D.M. THE papers in this book wore given at an intornational symposium on hypotensive peptides held in October, 1965. Fach chaptor is an individual research paper, and so the book is likely to be more useful to the specialist than to someone who is seeking a readable review concerning those interesting substances.

Nomenclaturo of these polypeptides has become so involved that the same substance is often known by two or more different names. A committee of the Florence conforence rocommended that the term "kinin" should be used as a general name indicating a hypotensive polypeptide which is released from plasma substrate (kininogon) by the action of an endogenous enzyme (kallikrein). Bradykinin, one of the most important of these compounds, is a nona peptide isolated in 1961 by the action of trypsin on a bovine plasma fraction. 